\title{
Education for inclusion: numeracy intervention in second chance education of market women in rural Nigeria
}

\author{
Igwe, Justina Ngozi ${ }^{1}$, Nzeadibe, Augustina Chinyere ${ }^{2}$, Ugwuanyi, Christian \\ Sunday ${ }^{2}$ \\ ${ }^{1}$ Department of Adult Education, University of Nigeria, Nsukka \\ ${ }^{2}$ Department of Science Education, University of Nigeria, Nsukka \\ Email: chinyere.nzeadibe@unn.edu.ng
}

\begin{abstract}
Background: A second chance education intervention was initiated for market women in rural Nigeria, who previously missed opportunity for formal education in their younger ages, with the aim of acquiring and improving basic numeracy skills for inclusion of the women.

Data source and methods: Thirty (30) questionnaires on hands-on activity were administered on 30 women purposively selected from the membership list of the association of market women, while 15 other women were similarly sampled to form the control group, giving a total of 45 questionnaires. Indepth interviews, and two focus group discussions (FGDs) comprising 12 volunteer women each were also conducted. The qualitative data were content analysed while mean, standard deviation, Chi-square and Analysis of covariance (ANCOVA) were used to analyse the quantitative data.

Results: Participants have similar socio-demographic characteristics. Over $70 \%$ of the respondents were aged less than 40 years while over $50 \%$ of the respondents attained primary education. Similarly, $64.4 \%$ of the rural women had no opportunity for formal education as adults. Results showed that there were significant effects of hands-on activities on mean ability of rural women in giving balance and stock taking.

Conclusions: The second chance education initiative provided an avenue for peer learning and more inclusive and equitable numerical skill development of market women, thus enhancing the prospect of contributing to AU Agenda 2063 and the 4th goal of the post-2015 development agenda.
\end{abstract}

Keywords: second chance education, sustainable development goals, numeracy, market women, inclusion

\section{Introduction}

Adult education is sometimes described as 'second chance', offering adults a chance to re-access educational systems or to re-train in new educational skills and knowledge (Adewale 2009, Grummell 2007). It is education and training that provides opportunities to young and old excluded people who lacked the skills and qualifications to enter further training or the job market (Babanzara 2017). Exclusion from meaningful participation in the economic, social, political and cultural life of communities is one of the greatest problems facing individuals in our society today (UNESCO 2006a). Instructively, education is a cultural activity that leads to empowerment and inclusion of populations. The sustainable development goals (SDGs) aim to provide inclusive and equitable quality education at all levels especially those in vulnerable situations (United Nations Department of Economic and Social Affairs 2015; Ajaero et al 2018). The education goal of the SDGs is geared towards enabling such vulnerable persons to have access to life-long learning opportunities that help them acquire the knowledge and skills needed to exploit opportunities and to participate fully in society.

Similarly, the Agenda 2063 of the African Union (African Union 2015) articulated a range of ideas and aspirations to achieve a prosperous Africa based on inclusive growth and sustainable development. It aspires for an Africa that shall be a prosperous continent, with the means and resources to drive its own development, with sustainable and long-term stewardship of its resources. Aspiration 10 no. 2 of the African Union Agenda 2063 envisions well educated and skilled citizens, underpinned by science, technology and innovation for a knowledge society where no child misses school due to poverty or any form of discrimination. In other words, AU Agenda 2063 foresees an Africa, whose development is people-driven, relying on the potential of African people, especially its women and youth, and caring for children (Aspiration 6 of the Agenda 2063). 
Unfortunately, these platitudes seem to be hampered by the continued exclusion of some segments of the population from the benefits of formal education especially with regard to numeracy. One such group of the rural population in Nigeria that is often excluded is market women. Market women in rural areas of Nigeria often have inadequate numerical skills for use in their daily transactions (Chuks 2004; Izugbara 2004). Numeracy is an important skill necessary for inclusive and equitable development and for promoting lifelong learning for all under the framework of the Sustainable Development Goal 4 (SDG 4). Previous research on second-chance education in Nigeria has examined the subject as an opportunity for socio-economic development (Babanzara 2017) but failed to explicate the role of improved numeracy in second chance education in the inclusion of rural market women in society. In the light of the SDGs, therefore, the need to integrate numeracy into second chance education of Nigerian rural women cannot be over-emphasized (Chuks 2004).

Furthermore, effective market transactions depend to a large extent on the ability of the prospective buyer and seller to communicate appropriately which often entails some form of numerical conversation. Numeracy is, thus, the ability to read and understand the language of figures (Obi 2006). Instructively, a significant proportion of the market women do not have formal education that could enable them to carry out some basic numerical tasks such as taking of stock, giving of balance to customers, addition, subtraction or even multiplication where necessary (Chuks 2004). This scenario is re-echoed by lzugbara (2004: 8I) who notes the lack of literacy and numeracy training in micro-credit schemes for market women in Nigeria. This author argues that 'the absence of literacy and numeracy training in the schemes, for instance, often resulted among other things, in the reliance of benefiting women on their husbands to keep the accounts, which is most likely to perpetuate rather than challenge the basis of women's subordination'.

At this juncture, it is pertinent to situate the concept of second chance in Nigeria education. Second chance is education specifically targeted at individuals who, for a variety of reasons, never attended school or left school either before completion of the level of education in which they were enrolled or completed the level but wish to enter an education programme or occupation for which they are not yet qualified (UNESCO Institute for Statistics 201I). In Nigeria, second chance education has been described as part of approaches to reach the most marginalized girls and women (Ajayi 20II). Non-formal approach to eradicate illiteracy in Nigeria which could also be described as second chance education often target children, youths and adults who have either dropped out of school before achieving permanent literacy or have never been to school due to a number of factors (Adewale 2009). Indeed, some state governments in Nigeria notably Sokoto state recently embarked on second chance education initiatives of women and girls. In this context, about 20,000 out-of-school girls and women will be assimilated into the formal school system in Sokoto State, under the European Union/United Nations Spotlight Initiative Second Chance Education for Women and Girls (Olugbemi 2019). The Federal Government of Nigeria also encourages State Governments to establish Girls' Second Chance Education Centers, where girls who dropped out of school can continue learning academic subjects, as well as specific technical skills and to provide adequate restructuring of such facilities including provisions of equipment and of facilitators' salaries (Federal Ministry of Education Nigeria 2006, 14).

Unfortunately, very little research has focused on numeracy in second chance education of vulnerable and excluded populations such as rural market women in Nigeria who depend on petty trading for a livelihood and who may suffer monetary losses in their businesses on account of possession of poor numerical skills (Chuks 2004). In addition, there is dearth of research on the effects of "hands-on activity in appraising efficacy of second chance education in improving numeracy of excluded populations namely rural market women. By hands-on is meant learning by experience (Holstermann et. al 2010:744). It is teaching method in which the learners use their hands in carrying out activities that could enhance their experiences under the guidance of the teacher. Hands-on activities include physical counting of the goods (stock-taking) and actual giving of balance to customers. Hence this study focused on integrating numeracy into second chance education of market women in rural Nigeria, using the hands-on activity method as a strategy to achieve the Agenda 2063 aspirations of inclusive growth and sustainable development.

Three research questions are addressed in this paper. The first investigates the effect of hands-on activities on mean ability of rural women in giving balance to customers. The second research question focuses on the effect of hands-on activities on mean ability of rural women in stock taking while the third research question addresses how improved numerical skills can contribute to inclusion of the rural women. 
Two null hypotheses and two alternate hypotheses at 0.05 level of significance are posed to guide the study:

Hol: There is no significant effect of hands-on activities on mean ability of rural women in giving balance to customers.

$\mathrm{Ha}_{\mathrm{a}}$ : There is a significant effect of hands-on activities on mean ability of rural women in giving balance to customers.

Ho2: There is no significant effect of hands-on activities on mean ability of rural women in stock taking.

$\mathrm{Ha}_{2}$ : There is a significant effect of hands-on activities on mean ability of rural women in stock taking.

The next section of this paper will attempt to articulate the nexus between inclusive education and sustainable development.

\section{Literature review and theoretical framework}

In the early 2 Ist century, inclusion has emerged as an overarching concern in international development and may also remain so in the foreseeable future. In fact, the term inclusive development has been featured prominently in a series of scholarly and policy documents to drive the post-2015 development agenda (Pouw and Gupta 2017:104). Within the context of an inclusive framework, the needs of disadvantaged and marginalized people are emphasized in development policy and practice including improving education processes and capacity building to enable them to use available opportunities (Pouw and Gupta 2017). In particular, inclusive education is regarded as a means to secure equal educational rights for all persons with varied special educational needs as it increases the democratic values of education and social justice (Haug 2017:214).

While some narrow definitions of inclusion tend to focus exclusively on special education and children with special needs (e.g. Norwich 20I4; Arduin 20I5), broad approaches to inclusion concerns all students and marginalized groups and not only those with disabilities (Thomas 20I3). Taking this broad view, UNESCO (2006a) posits that inclusion is a process of addressing and responding to the diversity of needs of all learners through increasing participation in learning, cultures and communities, and reducing exclusion within and from education. Thus, Haug (2017: 214) recently argued that 'the basic ideas behind inclusive education relate to dominating and common democratic values and social justice'. In sum, it would seem that social justice and sustainability mutually reinforce each other in inclusive education (McGregor et al 2015; Shyman 2015).

Similarly, it has also been argued that inclusive education can be a catalyst for attaining sustainable 5003 peace (Uchem et al 2014) particularly as inclusion is central to the SDGs (Mbah and Nzeadibe 2017). However, recent research posits that it is doubtful if the voice of marginalized groups such as rural market women is heard in educational issues that concern them (Quigley et al 2017). As a result, such populations are invariably excluded from mainstream governance and policy systems relating to education and skill development further reinforcing the need for inclusion of rural market women in Nigeria through a second chance education intervention.

While in the continent of Africa, Uchem and Ngwa (20l4) have provided evidence on practical inclusive education implementation in post-apartheid South Africa with a view to drawing lessons for other African nations, basic education in Nigeria which purportedly entails a nine-year compulsory programme with the aim of equipping the youths with basic knowledge and skills needed to proceed to higher levels of education, enter the world of work and earn a living, and contribute to the wellbeing of the society (Federal Republic of Nigeria 20/3) remains far from achieving the objectives of inclusive education (African Union 2015). More importantly, while the Federal Government's current development blueprint, the Economic Recovery and Growth Plan (ERGP) aims, among other things, to guarantee access to basic education for all (Federal Republic of Nigeria (2017:12), very little seems to have been done in the direction of second chance education of rural women. Thus, many women in rural areas of Nigeria inadvertently missed the opportunity for formal education at their younger ages despite the existence of this platitude in Nigerian educational policy and the AU Agenda 2063 (Federal Republic of Nigeria 2013, African Union 2015).

Fortuitously, second chance education evolved to provide an outlet to people who missed the opportunity of formal schooling at young age the opportunity to acquire formal education and skills necessary for living but who lacked the skills and qualifications to enter further training or the job market (Babanzara 2017).Such individuals who missed an opportunity for formal education at younger ages inevitably remain vulnerable and excluded. Thus, the main thrust of second chance education is to contribute to their social inclusion and cultural development (Nordlund et al 2013). In other words, to support both individuals and also to have sustainable society, second chance education should be available for low- educated adults.

In this regard, second chance education is considered as a particular form of education, distinguished by the population it addresses, that is adults (Nordlund et al 20I3). It is a situation whereby an adult who wished to improve his or her grades or 
invest in education could enroll in second chance education. Numeracy, on the other hand, is an integral part of education and is the ability to read and understand the language of figures (Obi 2006). A numerate person is able to reason with numbers and other mathematical concepts and to apply these in his day to day activities in solving problems. The need to employ numbers is necessary in every society that adopts certain activities as part of their way of life. Such activities include some social and cultural events which are symbolized by monetary and material exchanges during marriages or even the measuring and weighing activities that are often carried out in markets.

While rural women make substantial contributions to households and communities particularly in engaging in income-generating activities such as trading (Chuks 2004; Nzabona and Ntozi 2017), communication is a sine qua non to effective transactions in the market by both the buyers and sellers. The communication may be in form of oral communication or numerical communication. Since numeracy is the ability to read and understand the language of figures (Obi 2006), it is important for traders especially market women to imbibe numeracy in their day- to-day market interactions. This scenario can lead to individual and collective agency of rural market women in inclusive finance/business (Gupta and Pouw 2017) and financial literacy (Visano and Ek-Udofia 2017).

Instructively, the broad aim of Goal 4 of the SDGs is to 'ensure inclusive and equitable quality education and promote lifelong learning opportunities for all' (United Nations Department of Economic and Social Affairs 2015). Specifically, target 4.6 requires that by 2030 , all youth and a substantial proportion of adults, both men and women, achieve literacy and numeracy while target 4.7 seeks to 'ensure that all learners acquire the knowledge and skills needed to promote sustainable development, including, among others, through education for sustainable development and sustainable lifestyles, human rights, gender equality, promotion of a culture of peace and non-violence, global citizenship and appreciation of cultural diversity and of culture's contribution to sustainable development by 2030'(United Nations Department of Economic and Social Affairs 2015). Literacy, numeracy and the acquisition of knowledge and skills of adults to achieve gender equality are therefore central to the targets 4.6 and 4.7 (Milana et al. 20I8). The study under reference is perhaps the most comprehensive and up-to-date volume on the subject of lifelong learning in the context of the SDGs further validating the relevance of the present research on numeracy and second chance education.
While the post-2015 development Agenda places education at the centre of the attainment of many of the other sustainable development goals, such as Goal 3 Health and Well-being, Goal 5 Gender Equality, Goal 8 Decent Work and Economic Growth, Goal 12 Responsible Consumption and Production and Goal 13 Climate Change Mitigation, the conception of education in these different goals draws on the underlying values of much adult and lifelong education and learning practice (Webb et al 2017:509). Thus, the UNESCO considers adult learning and education as inseparable in the quest for sustainable development (Milana et al 2017:626). It is noteworthy that hands-on is one situational factor that is known to evoke students' interest and motivate them to learn science (Bergin 1999). In this context, Simpson (2003: 297) avers that "hands-on activities provide a means to actively engage students in the classroom, allowing students to become 'active, interested, and informed participants in the learning process'. Under this condition, students have a directed (either through an activity or an exercise) hands-on experience (Pfaff and Weinberg 2009).Thus, hands-on activities are often synonymous with materials-centered activities, manipulative activities and practical activities (Ateş and Eryilmaz 20II) and are important approaches to enhance students' achievement in science and technology education (Sadi and Cakiroglu 20II) including numeracy.

From the fore going, it is evident that numeracy is critical to achieving sustainable development of adults especially women who are often vulnerable in societies around the world. Hence, a well designed second chance education package could be utilized in our rural communities to sensitize rural market women on the need to acquire basic numeric skills and attitude for learning. The ability to read, write, calculate and perhaps including a sense of engagement with the education or training system will go a long way to instill in them the confidence, the willingness and motivation to learn continually while also fostering inclusion in line with the SDGs targets (United Nations Department of Economic and Social Affairs 20I5). This view is based on the premise that education is a major cultural activity critical for promoting sustainable development (UNESCO, 1992; Milana et al. 2017; Ajaero et al 20I8; Nzeadibe et al. 20।8; Webb et al. 20I7).

\section{Data and methods}

Quasi-experimental design, in which an experimental and control groups are investigated, was adopted in this research. The two groups have similar socioeconomic characteristics since they live within the same community and have similar cultural 
attributes. The fieldwork for the study was carried out over a six -week period in February and March 2018 at the Nkwo lbagwa market in Igbo-Eze South Local Government Area of Enugu State. The population of the study comprised about 226 registered rural women that do their business at the Nkwo lbagwa market. Forty five (45) women in the garri selling sector of the market were sampled representing $20 \%$ of the population in the membership list. These are the regular traders in the market who were willing to participate in the study. The choice of garri sellers was predicated on the fact that garri is a staple food in the area and high quality garri is known to be traded in the market. Similarly, being a periodic market, the traders usually accumulate the commodity from farming and garri processing households to be sold in this market which serves the nutritional needs of the University of Nigeria Community and the nearby urban area of Nsukka. The item (garri) is predominantly sold by women in the market. Hence, women garri sellers were chosen for the study.

The study adopted the mixed methods approach in data collection and analysis. Respondents were selected using purposive sampling technique. Purposive sampling was applied to enable the researchers target market women who were not able give correct balance to customers and as well take stock of their goods prior to the intervention. Assistance of the executive committee of the market women association was enlisted in identifying and recruiting the respondents. As a result, thirty (30) market women were purposively selected from the membership list of the of the garri sellers' market women association to constitute the experimental group while fifteen (I5) women were similarly selected from the membership of the group to form the control group.

The choice of 45 women (i.e 20\% of the population) for the experimental group and control group was to enable a significant proportion of the market women to benefit from the second chance education intervention. The instruments for data collection were the in-depth interview (IDI) schedule and focus group discussion (FGD) guide. The IDI schedule and FGD guide contained unstructured questions to allow the researchers to further interrogate issues which were not included in the schedule and guide but which were within the scope of the study (Ebimgbo et al 2019). Each IDI lasted approximately 40 minutes while FGDs lasted for 90 minutes each. The IDIs and FGDs were conducted in the late afternoon to early evening (non-peak market periods) when the women were concluding their sales for the day and had few customers to attend. The lead investigator moderated the interview and discussions while the co-investigators took notes. Adapting the method of Ebimgbo et al (2019) and Chukwu et al (2019), the IDls and FGDs were conducted in the Nsukka dialect of the lgbo language to which two of the researchers were fluent in speaking and proficient in writing.

Two focus groups were conducted with the women. Each focus group was made up of 12 volunteer women. The IDIs and FGDs were audiorecorded and initially transcribed in the lgbo language and later translated verbatim into the English language to enable accurate presentation of exact meanings in both languages. Content analyses of the transcripts were conducted to identify common threads and significant responses. Hands-on practical work was also undertaken. Each of the market women was interviewed based on the ability to give balance and take stock of their goods. The data generated from both IDIs and FGDs were used to support the discussion of the findings obtained from the hands-on practical work.

The characteristics of the women considered are age, level of education, marital status, type of business, religion, daily income and husbands' occupation. Questions regarding the patriarchal character of access and exposure to education during the younger years of the women, and their perception of second chance education were also asked. Two females in the research team led in the data collection in recognition of socio-cultural sensitivities in the target rural communities. Interviews, focus group discussion and hands- on practical work were conducted with market women groups at the Nkwo lbagwa market in Nsukka LGA of Enugu State of Nigeria (Figure I and Figure 2). This site was selected because it is a rural periodic market that serves the Nsukka urban area, where the University of Nigeria is located (Madu 2007). A large number of urban residents patronize the market on account of the relatively low cost of food items and other goods sold in the market.

Prior to the experiment, the market women were pre-tested on their ability to give correct balance and take stock of their goods after which the second chance education intervention (experiment) started. The experiment lasted for six weeks which were in three sessions per week. In each of the sessions, the market women were drilled on hand-on activities on giving balance and how to take stock of goods. The sessions were mainly in the evening time from $5 \mathrm{pm}$ to $6 \mathrm{pm}$ (non-peak market periods). This time was chosen so that the women can concentrate on the activity. The control group was not given such drill. At the end of the six weeks, the experimental group and the control group were post-tested on their 
ability to give correct balance and take stock of their goods.

The data collected on the hand-on practical work were analysed using percentage, mean, standarddeviation, Chi-square and Analysis of covariance (ANCOVA). Chi-square was used to analyse the difference in the independent samples with respect to the socio-demographic characteristics of the participants before the treatment. The ANCOVA was used in order to take care of the differences in the groups. Such differences are unequal number of subjects in each of the groups and the initial differences among the market women. The dependent variable in this study is rural women's numerical ability i.e the ability of the rural women to take stock of their goods and give correct balance to customers. Hands-on activities were the independent variable for the study. The rural women in the treatment group were engaged in hand-on activities for a period of 6 weeks. The women in the control group were not subjected to such activity. However, prior to the treatment period, both groups were given numeracy test as pre-test and at the end of the treatment. The same numeracy test was administered to the groups as posttest.

\section{Ethical considerations}

The objectives of the study and methods to be used were clearly explained to the participants who gave their free prior informed consent to participate. The researchers presented letters of letter of identification from the University of Nigeria authority to the leaders of Ibagwa community to seek approval for the conduct of the research. Based on that, the approval for the conduct of the research was granted by the community leaders. Given the rural character of the study population and the sensitive nature of the study, the researchers did not insist on signed consent. Thus, the researchers obtained from the participants only verbal consent to conduct the study and for audio recording of discussions. The researchers also observed all ethical issues in research during the course of the study.

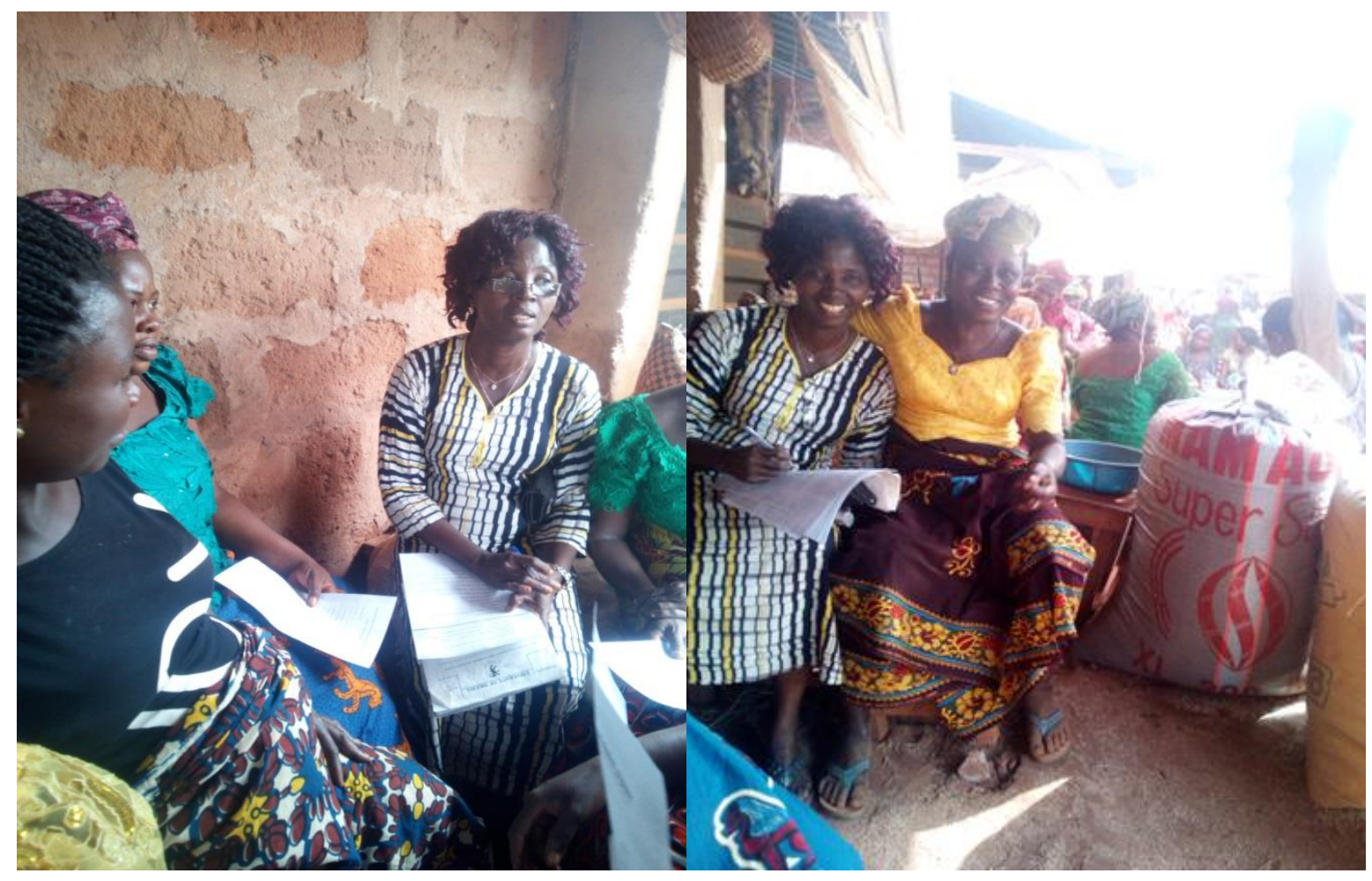

Figure I and Figure 2: Scenes from focus group discussion with garri sellers (Source: Fieldwork 2018)

\section{Results}

In order to contextualize the study, the sociodemographic characteristics of the rural market women were examined. Table I presents the sociodemographic characteristics of the participants as obtained during the fieldwork. 
Table I: Socio-demographic Characteristics of the Participants

\begin{tabular}{|c|c|c|c|c|}
\hline Characteristics & $\begin{array}{l}\text { Treatment } \\
\text { n (\%) }\end{array}$ & $\begin{array}{l}\text { Control } \\
\text { n (\%) }\end{array}$ & $X^{2}$ & p-value \\
\hline \multicolumn{5}{|l|}{ Age } \\
\hline $21-30$ years & $8(26.7)$ & $2(13.3)$ & \multirow{4}{*}{6.00} & \\
\hline $31-40$ years & $9(30.0)$ & 6(40.0) & & .306 \\
\hline $4 I-50$ years & $10(33.3)$ & 6(40.0) & & \\
\hline 50 years and above & $3(10.0)$ & $\mathrm{I}(6.7)^{\prime}$ & & \\
\hline \multicolumn{5}{|l|}{ Level of Education } \\
\hline No Formal Education & $\mathrm{II}(36.7)$ & $7(46.7)$ & \multirow[t]{3}{*}{10.00} & .350 \\
\hline Primary & 14(46.7) & $6(40.0)$ & & \\
\hline Secondary & $5(16.6)$ & $2(13.3)$ & & \\
\hline \multicolumn{5}{|l|}{ Marital Status } \\
\hline Single & $4(13.0)$ & $2(13.6)$ & \multirow[t]{4}{*}{8.00} & .333 \\
\hline Married & $13(43.5)$ & $6(40.9)$ & & \\
\hline Widow & $8(26.1)$ & $3(18.2)$ & & \\
\hline Separated & $5(17.4)$ & $4(27.3)$ & & \\
\hline \multicolumn{5}{|l|}{ Religion } \\
\hline Christianity & $18(60.0)$ & $9(60.0)$ & \multirow{3}{*}{3.07} & \multirow{3}{*}{.891} \\
\hline Muslim & $3(10.0)$ & $2(13.3)$ & & \\
\hline African Traditional Religion & $9(30)$ & $4(26.7)$ & & \\
\hline Daily Income & $8(26.7)$ & & & \\
\hline $1000-2500$ & $13(43.3)$ & $6(40.0)$ & 11.04 & .086 \\
\hline$\$ 3000-\$ 5000$ & $9(30.0)$ & $5(33.3)$ & & \\
\hline Above 5000 & & $4(26.7)$ & & \\
\hline \multicolumn{5}{|l|}{ Husband's Occupation } \\
\hline Civil Servant & $2(9.1)$ & $\mathrm{I}(8.3)$ & & \multirow{4}{*}{.732} \\
\hline Artisan & $\mathrm{II}(50.0)$ & $7(58.4)$ & \multirow[t]{3}{*}{5.63} & \\
\hline Driver & $3(13.6)$ & $\mathrm{I}(8.3)$ & & \\
\hline Trader & $6(27.3)$ & $3(25.0)$ & & \\
\hline
\end{tabular}

Table I shows that there is no significant difference in the age, level of education, marital status, type of business, religion, daily income and husbands' occupation of rural women in the treatment group and those in the control group, $=6.00, p=.306 ;=$ $10.00, \mathrm{p}=.350 ;=8.00, \mathrm{p}=.333 ;=3.07, \mathrm{p}=$ $.891 ;=7.00, p=.456 ;=11.04, p=.086 ;=5.63$, $\mathrm{p}=.732$. This implies that the participants in the treatment and control groups are similar in terms of their socio-demographic characteristics.

Similarly, the study sought to find out the effect of hands-on activities on mean ability of the rural market women who were exposed to hands-on activities in giving balance and those not so exposed in giving balance to customers (Table 2).

Table 2: Mean and standard deviation of ability of rural women to give balance

\begin{tabular}{|c|c|c|c|c|c|c|}
\hline \multirow[t]{2}{*}{ Treatment } & \multicolumn{3}{|c|}{ Pre-test } & \multicolumn{2}{|c|}{ Post-test } & \multirow[b]{2}{*}{$\begin{array}{l}\text { Mean } \\
\text { Gain }\end{array}$} \\
\hline & $\mathrm{n}$ & Mean & SD & Mean & SD & \\
\hline Exposed to Hands-on & 30 & 16.43 & 5.58 & 53.36 & 16.15 & 36.93 \\
\hline
\end{tabular}


Table 2 shows that the rural women who were exposed to hands-on activities had higher mean ability score $(M=53.36, S D=16.13)$ than those who were not exposed to hands-on activities ( $M=$ $35.80, \mathrm{SD}=19.68)$. Mean gain scores of 36.93 and 19.67 for the experimental and control groups respectively imply that the rural women who were exposed to hands-on activities had higher ability of giving balance to customers than those who were not so exposed.

Again, the effect of hands-on activities on mean ability of rural women in giving balance to customers was examined. Table 3 presents the results of covariance analysis on the effect of hands-on activities on mean ability of rural women in giving balance.

Table 3: Results of covariance analysis of the effect of hands-on activities on mean ability of rural women in giving balance

\begin{tabular}{|c|c|c|c|c|c|}
\hline Source & $\begin{array}{l}\text { Type III Sum of } \\
\text { Squares }\end{array}$ & Df & Mean Square & $\mathrm{F}$ & Sig. \\
\hline Corrected Model & $3893.322^{\mathrm{a}}$ & 2 & 1946.661 & 6.707 & .003 \\
\hline Intercept & 12604.375 & I & 12604.375 & 43.428 & .000 \\
\hline Pre-ability & 807.444 & I & 807.444 & 2.782 & .103 \\
\hline Treatment & 3175.647 & I & 3175.647 & 10.942 & .002 \\
\hline Error & 12189.922 & 42 & 290.236 & & \\
\hline Total & 117662.000 & 45 & & & \\
\hline Corrected Total & 16083.244 & 44 & & & \\
\hline
\end{tabular}

a. $\mathrm{R}$ Squared $=.242$ (Adjusted R Squared $=.206$ )

Table 3 shows that associated probability value for the calculated $F$ (10.942) for the effect of hands-on activities on mean ability of rural women in giving balance to customers, is 0.002 . Hol is that there is no significant effect of hands-on activities on mean ability of rural women in giving balance to customers. Since the probability value of 0.002 is less than the 0.05 level of significance, the null hypothesis was rejected. This implies that there is a significant effect of hands-on activities on mean ability of rural women in giving balance to customers. In other words, handon activities improved the ability of rural women in giving balance to customers.

The study further examined the effect of hands-on activities on mean ability of rural women in stock taking. Results of the effect of hands-on activities on mean ability of rural women in stock taking are presented in Table 4.

Table 4: Mean and standard deviation of effect of hands-on activities on mean ability of rural women in stock taking

\begin{tabular}{lrrrrrr}
\hline Treatment & \multicolumn{4}{c}{ Pre-test } & Post-test & \\
& $N$ & Mean & SD & Mean & SD & $\begin{array}{l}\text { Mean } \\
\text { Gain }\end{array}$ \\
\cline { 2 - 8 } & & & & & & \\
Exposed to Hands-on & 30 & 11.16 & 2.84 & 48.83 & 18.46 & 37.67 \\
Not Exposed to Hands-on & 15 & 13.66 & 5.16 & 28.80 & 5.97 & 15.14 \\
\hline
\end{tabular}

Table 4 shows that the rural women who were exposed to hands-on activities in stock taking had higher mean ability $(M=48.83, S D=18.46)$ than those who were not exposed to hands-on activities $(M=28.80, S D=5.97)$. Mean gain scores of 37.67 and 15.14 for the experimental and control groups respectively imply that the rural women who were exposed to hands-on activities had higher ability of stock taking than those who were not so exposed. Results of analysis of covariance of the effect of hands-on activities on mean ability of rural women in stock taking is presented in Table 5. 
Table 5: Results of analysis of covariance of the effect of hands-on activities on meanability of rural women in stock taking

\begin{tabular}{lrrrrr}
\hline Source & $\begin{array}{c}\text { Type III Sum of } \\
\text { Squares }\end{array}$ & Df & Mean Square & F & Sig. \\
\hline Corrected Model & $4015.155^{\mathrm{a}}$ & 2 & 2007.578 & 8.116 & .001 \\
Intercept & 5595.091 & $\mathrm{I}$ & $5595.09 \mathrm{I}$ & 22.620 & .000 \\
Pre-stocking ability & $1.81 \mathrm{I}$ & $\mathrm{I}$ & $1.81 \mathrm{I}$ & .007 & .932 \\
Treatment & 3589.549 & $\mathrm{I}$ & 3589.549 & 14.512 & .000 \\
Error & 10388.756 & 42 & 247.351 & & \\
Total & 94373.000 & 45 & & & \\
Corrected Total & $\mid 4403.911$ & 44 & & & \\
\hline
\end{tabular}

a. R Squared $=.279$ (Adjusted R Squared $=.244$ )

Table 5 shows that associated probability value for the calculated $F(14.5 \mid 2)$ for the effect of hands-on activities on mean ability of rural women in stock taking, is 0.000 . Ho2 is that there is no significant effect of hands-on activities on mean ability of rural women in stock taking. Since the probability value of 0.000 is less than the 0.05 level of significance, the null hypothesis was rejected meaning that there is a significant effect of hands-on activities on mean ability of rural women in stock taking. In other words, handon activities improved the ability of rural women in stock taking.

\section{Discussion}

The findings revealed that the participants in the treatment and control groups were equivalent in terms of their socio-demographic characteristics meaning that any observed difference in the numeracy of the two groups of rural women was attributed to the effect of hand-on activities. The women exposed to second chance education tended to better imbibe numeracy after interaction with one another. The study showed that there is a significant effect of hands-on activities on mean ability of rural women in stock taking. Furthermore, the results indicated that there is a significant effect of hands-on activities on the mean ability of rural women in giving balance to customers. Similar results were obtained by Izugbara (2004) regarding micro-lending and improved numeracy and empowerment for rural women. Thus, working with women's groups was more effective and interactive than with women not part of the group.

In addition, over $50 \%$ of the respondents attained primary education in their childhood. Similarly, $64.4 \%$ of the rural women had no opportunity for formal education as adults. This indicates that majority of the rural women in the study did not have opportunity for formal education as adults. As a result, this category of women falls within the vulnerable and excluded groups of individuals in society, a situation that could inhibit the attainment of SDG 4. This scenario would invariably necessitate development interventions in the areas of second chance education as an opportunity to enhance the capacity of the women in literacy and numeracy.

It is noteworthy that early marriage was a widespread phenomenon in the area in the past. Hence, it tended to preclude girls from acquiring formal education when the women were younger. The women raised some vital issues bordering on their exclusion from formal education on account of early marriage during their younger ages. In response to a question about their low level of education, a 45year old participant stated as follows:

During our growing time in the villages, women were considered as assets to their husbands alone. When we enroll in schools, our training does not benefit our families. As a result, we were not allowed to enroll into schools rather we were given out in marriage because we were expected to bear children and keep our husbands happy.

Stubborn female children were usually the ones that benefitted (by default) from education as a way of punishing them. Women who managed to go to school were seen in the community as not being humble. They were also regarded as tough and unlikely to be submissive to their husbands. Such women are called Tacha (a reference to the former British Prime Minister, Margaret Thatcher, widely regarded as a tough personality).

My brothers were trained in school while I was not trained because my family members felt that training me was of no value to my family. 
If, however, a girl enrolls in school and subsequently gets married, the husband had the final say whether she will 'work' or stay at home to cater for the children. According to a participant 'education of women at that time was considered a waste of time and resources' because it was better to train the boys than the girls. The cliché that 'women's education ends in the kitchen' was often cited. But we now know that there is no element of truth in this erroneous belief.

The above responses during the FGDs show clearly the systemic societal structures that institutionalize male physical, social and economic power over women (Reeves and Baden 2000: 28) which have necessitated this second chance intervention initiative as a strategy for inclusive growth and sustainable development of market women in rural Nigeria. A respondent, Madam Chijioke, however, sees the prospects inherent in training females in school. According to her:

Although I was not trained in school, I am happy that today all my female children are educated, with some of them in the UNN (University of Nigeria, Nsukka). This is because I would not want my female children to undergo the same experience that I had.

As regards their trading activities, some respondents stated that they usually do differentiate the stocks of one item of trade from the other. As a result, they are unable to keep track of their profits or losses on individual goods. Often, the women incur losses on individual goods while making profits in others but are unable to properly account for different items in their petty trading activities. 'All I am concerned about is to make profits no matter from which item I make the sales' stated another participant.

Many of the women were able to give correct balance to their customers when the customers buy their goods. A 54-year old respondent remarked as follows during an IDI: 'I am able to give correct change because I have been in this business for many years'. Here, experience and the hands-on activity are the keys to their ability to give correct balance because they recognize the various denominations of the Nigerian currency, the Naira from their years of buying and selling. Just as Izugbara (2004) suggests that micro-credit lending was a form of empowerment for rural women, this study is of the view that the second chance education initiative for market women represents a contribution to women inclusion and gender equality and empowerment SDG.
Interestingly, interactions during the FGDs tended to portray them as desirous of second chance education. As participants in one FGD noted:

We know that school helps people to improve their lives and make more money in business. We would like to enroll in adult classes in order to improve ourselves. May be it will help us in our trading activities here in the Nkwo market and at home. Some of our educated friends sometimes look down on us during meetings in the community because we can't speak the language of oyibo people (i.e white men). So, we would like to show them that we can also talk like oyibo people when we get educated.

A number of participants, however, noted the constraint imposed on them by time but are of the view that their children can acquire the education which they themselves missed during their younger days.

How can improved numerical skills contribute to inclusion of the rural women?

African Union Agenda 2063 envisions that 'all the citizens of Africa will be actively involved in decision making in all aspects'. Accordingly, 'Africa shall be an inclusive continent where no child, woman or man will be left behind or excluded, on the basis of gender, political affiliation, religion, ethnic affiliation, locality, age or other factors'. In addition, 'all the citizens of Africa will be actively involved in decision making in all aspects of development, including social, economic, political and environmental'. We argue that second chance education of rural market women could present a platform to actualize these aspirations of AU Agenda 2063 related to inclusive growth and sustainable development. In this study, second chance education offered opportunity to women who previously missed formal education in their younger ages. It also provided avenue to improve numeracy of the women in market transaction. It is concluded that second chance education of women groups can provide an avenue for peer learning and more inclusive and equitable numerical skill development among market women, thus enhancing the prospect of achieving the 4th goal of the post-20I5 development agenda.

Arguably, the intervention in second chance education discussed in this paper is a strategy for inclusion of market women in rural Nigeria. While the primary focus of this research is the education goal, integrating numeracy in second chance education can also have trickle down effects on other SDGs particularly goal 5 relating to gender empowerment and equality. Overall, this will lead to 
a more inclusive and prosperous society going forward.

\section{References}

Adewale, J.G.(2009). Effectiveness of non-formal education programs in Nigeria: how

competent are the learners in life skills? Australian Journal of Adult Learning 49 (I), 190-207.

African Union Commission (2015). Agenda 2063: The Africa We Want. Addis Ababa: African Union Commission, ISBN: 978-92-95 I04-23-5

Ajaero, C.K., Nzeadibe, T.C and Ezeibe, C.C. 20I8). University of Nigeria Nsukka research

and post-2015 development. African Population Studies 32, No 2 (Supp), 4 I09-4II 2.

Ajayi, H.O. (20II).Approaches to Reach and Teach the Most Marginalized Children in Nigeria: The Girl-Child Education. African Research Review 5 (3),8I-89.

Arduin, S. (20I5). A Review of the Values that Underpin the Structure of an Education System and Its Approach to Disability and Inclusion. Oxford Review of Education 4I (I): |05-|2I.

AteşÖ. and Eryilmaz, A.(201 I). Effectiveness of hands-on and minds-on activities on students'

achievement and attitudes towards physics. AsiaPacific Forum on Science Learning and Teaching, I2(I)

Babanzara, U.H.(20I7). Utilizing second chance education: Means for socio-economic development potentials in Nigeria. Journal of Nigerian National Council for Adult Education, 22(2), 326-346.

Bergin, D. A. (1999). Influences on classroom interest. Educational Psychologist, 34, 87-98.

Chuks, O.B.(2004).Literacy/numeracy and vocational training among rural women in Nigeria for a good livelihood and empowerment. International Journal of Lifelong Education, 23 (3), 287-299.

Chukwu, N.E., Okoye, U.O., Onyeneho, N.G. and Okeibunor, J.C. (2019). Coping strategies of families of persons with learning disability in Imo state of Nigeria. Journal of Health, Population and Nutrition 38:9, I-9. https://doi.org/I0.II86/s4I043-019-0168-2

Ebimgbo, S.O., Obi-Keguna, C.N., Chukwu, N.E., Onalu, C.E., Abonyi, S.E and Okoye, U.O (2019). Culture-based social support to older adults in Nnewi, South-East Nigeria. African Population Studies 33 (2) 489I-4900.

Federal Ministry of Education Nigeria (2006). National policy on gender in basic education. Abuja: Federal Ministry of Education.

Federal Republic of Nigeria (20/3). National Policy on Education (6th edition). Lagos. NERDC press.
Federal Republic of Nigeria (2017). Economic Recovery \& Growth Plan 2017-2020. Abuja: Ministry of Budget \& National Planning.

Grummell, B. (2007). The 'second chance' myth: equality of opportunity in Irish adult education policies. British Journal of Educational Studies Vol 55:2, pp. |82-20|.

Holstermann, N., Grube, D., and Bögeholz, S. (2010) Hands-on Activities and Their Influence on Students' Interest. Research in Science Education 40:743-757

Gupta, J. and Pouw, N.(2017). Towards a transdisciplinary conceptualization of inclusive

development. Current Opinion in Environmental Sustainability 24: 96-103.

Haug, P. (2017). Understanding inclusive education: ideals and reality. Scandinavian Journal of Disability Research, 19(3), 3, 206-217.

Izugbara, C. O. (2004). Gendered micro-lending schemes and sustainable women's

empowerment in Nigeria. Community Development Journal, 39(I), 72-84.

Madu, I.A (2007).The underlying factors of rural development patterns in the Nsukka Region of Southeastern Nigeria. Journal of Rural and Community Development, 2, I I0-I 22.

Mbah, P.O and Nzeadibe, T.C. (2017). Inclusive municipal solid waste management policy in

Nigeria: Engaging the informal economy in post-2015 development agenda. Local Environment: The International Journal of Justice and Sustainability 22(2), 203-224. http://dx.doi.org//0.1080//3549839.2016. I I8806 2

McGregor, G., Mills, M, Riele, K and Hayes, D.(20I5). Excluded from school: getting a second chance at a 'meaningful'education. International Journal of Inclusive Education, 19 (6), 608-625

Milana, M., Holford, J., Hodge, S., Waller, R and Webb, S.(2017) Adult education and learning: endorsing its contribution to the 2030 Agenda International Journal of Lifelong Education, 36:6, 625-628, DOI: 10.1080/02601370.20I7.1405869

Milana, M., Webb, S., Holford, J., Waller, R., and Jarvis, P. (Eds.)(20I8). The Palgrave

International Handbook on Adult and Lifelong Education and Learning. London: Palgrave Macmillan.

Nordlund, M., Bonfanti, S. and Strandh, M (20/3). Second chance education matters! Income trajectories of poorly educated non-Nordics in Sweden. Journal of Education and Work, 28:5, 528-550.

Nordlund, M., Stehlik, T., and Strandh, M. (20|3). Investment in Second-Chance Education for adults 
and income development in Sweden. Journal of Education and Work, Vol. 26, No. 5, 5|4-538.

Norwich, B. (20|4). Recognising value tensions that underlie problems in inclusive education.

Cambridge Journal of Education, 44(4), 495-5I 0.

Nzabona, A. and Ntozi, J. (2017). Does education influence the value of older persons? Assessing socio-demographic determinants of older persons' value in Uganda. African Population Studies, 3 I (2) supp, 3694-3705.

Nzeadibe, A.C., Uchem, R.N and Nzeadibe, T.C.(2018).Beyond 'Traditional Geographies:' Integrating Urban Political Ecology and Cultural Sustainability into Undergraduate Geographical Education in Nigeria. The Journal of Environmental Education 49 (3), 228-24I, DOI: 10.1080/00958964.2017.139|| 62

Obi, G.O (2006). Dimensions and issues in adult literacy. Nsukka: Ephrata publishers.

Olugbemi, A.(2019). 20,000 Sokoto girls, women for second chance education. Punch

Newspapers, 20th December 2019. https://punchng.com/20000-sokoto-girls-womenfor-second-chance-education/

Pfaff, T.J and Weinberg, A. (2009). Do Hands-on Activities Increase Student Understanding? A Case Study. Journal of Statistics Education, 17:3,DOI: 10.1080/1069|898.2009.। I889536

Pouw, N. and Gupta, J. (2017). Inclusive development: a multi-disciplinary approach. Current Opinion in Environmental Sustainability 24:104-108.

Quigley, C. F., Che, S. M., Achieng, S., \& Liaram, S. (2017). Women and the environmental are together: Using participatory rural appraisal to examine gendered tensions about the environment. Environmental Education Research 23(6),

773-796. doi: I0.1080/|3504622.20|6.|I695 I I

Reeves, H. and Baden, S. (2000).Gender and Development: Concepts and Definitions. Report No 55 prepared for the Department for International Development (DFID) for its gender mainstreaming intranet resource. Brighton, UK: Institute of Development Studies.

Sadi, Ö and Cakiroglu, J.(20I I).Effects of hands-on activity enriched instruction on students' achievement and attitudes towards science. Journal of Baltic Science Education, I0(2),87-97.

Shyman, E. (20I5). Toward a Globally Sensitive Definition of Inclusive Education Based in Social Justice. International Journal of Disability, Development and Education, 62 (4), 35I-362,

Simpson, T.W. (2003). Experiences with a Hands-on Activity to Contrast Craft Production and Mass
Production in the Classroom. International Journal of Engineering Education I9( 2), 297-304.

Uchem, R.N and Ngwa, E.S.(2014).Inclusive Education Policy Implementation in Post-

Apartheid South Africa: Lessons for Nigeria and Cameroon. Journal of Education and Practice 5(36), 92-100.

Uchem, R.N., Ngwa, E.S and Asogwa, U.D.(20|4).Inclusive Education and Sustainable Peace in Africa, International Affairs and Global Strategy, 19, 48-54

UNESCO (1992, June 13). UN Conference on Environment and Development: Agenda 2I. Rio de Janeiro, Brazil: UNESCO.

UNESCO Institute for Statistics (20II) Second chance education. Retrieved on I0th January 2020 from: https://unevoc.unesco.org/go.php?q= tvetipedia + glossary $+\mathrm{a}$-z\&filt $=$ all\&id $=677$

United Nations Department of Economic and Social Affairs. (2015). Transforming our world: The 2030 Agenda for Sustainable Development. Sustainable Development Knowledge Platform. Retrieved from

https://sustainabledevelopment.un.org/content/do cuments/789| Transforming\%200ur\%20World.p df

Thomas, G. (20/3). A Review of Thinking and Research about Inclusive Education Policy, with suggestions for a New Kind of Inclusive Thinking. British Educational Research Journal 39 (3): 473490.

UNESCO.(2006a). Guidelines for Inclusion: Ensuring Access to Education for All. Paris:

UNESCO.

http://www.ibe.unesco.org/sites/default/files/Guid elines_for_Inclusion_UNESCO_2006.pdf

UNESCO (2006b) .Education For All (EFA) \& Inclusive Education A Renewed Discussion.

Paris: UNESCO.

http://www.ibe.unesco.org/sites/default/files/EFA a_renewed_discussion_Beirut.pdf

Visano, B.S and Ek-Udofia, I.(2017).Inclusive financial literacy education for inspiring a

critical financial consciousness: an experiment in partnership with marginalised youth. International Journal of Inclusive Education, 2 I (7), 763-774.

Webb, S., Holford, J., Hodge, S., Milana. M and Waller, R (2017). Lifelong learning for quality education: exploring the neglected aspect of sustainable development goal 4, International Journal of Lifelong Education, 36:5, 509-5II, DOI:I0.1080/0260I370.20I7.1398489. 